\title{
Teologia da Veste e os dispositivos de poder: notas sobre a relação nudez-veste
}

Theology of the Robe and the devices of power: notes on

the relationship nudity-robe

MARIANA PFISTER (Da

GLAuco BARSALINI (Db

\section{Resumo $^{1}$}

A relação do ser humano com o vestuário ultrapassa, segundo o teólogo católico Erik Peterson, as questões morais, uma vez que se dá primeiramente no campo metafísico teológico, após a queda do pecado original. A queda da natureza humana pelo pecado revelou a nudez, o despojamento do vestuário sobrenatural da glória. Esta afirmação do teólogo incitou o filósofo contemporâneo Giorgio Agamben, em seu ensaio sobre a Nudez, a pensar na relação nudez-veste como um dos mais antigos e poderosos dispositivos de poder na cultura ocidental. Nesse artigo, apresentaremos os meandros desta teologia da veste relacionando-a a outros conceitos analisados pelo filósofo como oikonomia trinitária, officium e inoperosidade.

Palavras-chave: Oikonomia. Officium. Inoperosidade. Nudez.

\footnotetext{
${ }^{1}$ Parte desse texto foi apresentado pela autora, enquanto comunicação, no $31^{\circ}$ Congresso Internacional da Sociedade de Teologia e Ciências da Religião (SOTER), e foi publicada em seus anais (2018). Agradecemos aos membros do GT 13 - Religião e Espaço Público pelo ambiente de debates que inspirou o desenvolvimento deste artigo, ao que somam-se contribuições posteriores de seu coautor. Agradecimentos à Fundação de Amparo à Pesquisa do Estado de São Paulo (FAPESP), pelo financiamento da bolsa de pesquisa de mestrado da autora [Processo no. 2017/12524-5].

a Pontifícia Universidade Católica de Campinas (PUC-Campinas), Campinas, SP, Brasil. Mestra em Ciências da Religião, e-mail: marianapft@hotmail.com

b Pontifícia Universidade Católica de Campinas (PUC-Campinas), Campinas, SP, Brasil. Doutor em Filosofia, e-mail: glaucobarsalini@gmail.com
} 


\section{Abstract}

According to the Catholic theologian Erik Peterson, the relationship between humans and clothing goes beyond moral issues, since it occurs primarily in the metaphysicaltheological field, after the fall of original sin. The fall of human nature by sin revealed the nakedness, the stripping of the supernatural garment of glory. This statement by the theologian prompted the contemporary philosopher Giorgio Agamben, in his essay on Nudity, to think of the nudity-dress relationship as one of the oldest and most powerful devices of power in Western culture. In this article, we will present the intricacies of this robe theology relating it to other concepts analyzed by the philosopher such as Trinitarian oikonomia, officium and inoperosity.

Keywords: Oikonomia. Officium. Deadness. Nudity.

\section{Introdução}

Através do método arqueogenealógico, um dos pontos centrais revelados pelo pensador contemporâneo Giorgio Agamben em seu projeto homo sacer é a investigação do termo grego oikonomia, que teve papel decisivo na história da Igreja entre os séculos II e VI, especificamente no que diz respeito à formatação da dogmática trinitária.

A oikonomia trinitária tornou-se um dispositivo eficaz para explicar a ideia de um governo divino providencial do mundo. Embora a utilização deste termo tenha sido adequada para solucionar a questão da existência de três pessoas divinas, acabou permitindo a criação de uma dolorosa fratura: a dissociação entre o Ser de Deus e sua práxis, sua ação governativa do mundo. Esta separação entre ser e ação, essência e operação, foi justamente o que forjou a experiência histórica da qual somos tributários e que, conforme Agamben, constitui-se como o alicerce da glorificação do poder soberano, dispositivo fundamental para o estabelecimento do estado de exceção e da consequente geração do homo sacer na modernidade e na contemporaneidade.

Ainda de acordo com o filósofo italiano, tão decisivo quanto a oikonomia é o dispositivo teológico que inaugura a era dos dispositivos na cultura ocidental: a relação veste-nudez. 
Neste artigo, realiza-se leitura imanente da obra de Agamben, com o objetivo de apresentar os fios que nutrem a malha oikonomica, relacionando teologia da veste à operatividade, cuja inscrição está pautada na dominação entre o vestido e o desvestido, o que garante práticas de soberania, precipitando a vida humana à condição de bando.

Ao ligar-se inoperosidade à forma-de-vida, nota-se que o contraponto ser e ação, formatado pelo dispositivo da veste, torna-se ineficaz, possibilitando rotas de fuga à opressiva oikonomia providencial divina.

\section{O operador estratégico}

Agamben resgata, do tratado aristotélico, o significado do termo oikonomia, — "administração da casa" (oikia refere-se à casa) —, em clara oposição à cidade — polis. Com o passar do tempo, essa oposição aristotélica oikos/polis foi esvaziada e os vocábulos economia e política relacionaram-se mutuamente a ponto de não mais se distinguirem. Mas, "como se chegou a falar de uma 'economia divina'?" (AGAMBEN, 2009, p. 35). Tratava-se de um problema extremamente delicado e decisivo na história da teologia cristã - a Trindade. A partir do século II, inicia-se uma acirrada discussão acerca das figuras divinas - o Pai, o Filho e o Espírito Santo - , na qual o grande temor era um retorno ao politeísmo e ao paganismo na fé cristã. A melhor maneira que teólogos como Tertuliano, Hipólito, Ireneu e outros encontraram foi a utilização do termo oikonomia:

$\mathrm{O}$ argumento destes era mais ou menos o seguinte: Deus, quanto ao seu ser e à sua substância, é, certamente, uno; mas quanto à sua oikonomia, isto é, ao modo em que administra a sua casa, a sua vida e o mundo que criou, é, ao contrário, tríplice. Como um bom pai pode confiar ao filho o desenvolvimento de certas funções e de certas tarefas, sem por isso perder o seu poder e a sua unidade, assim Deus confia a Cristo a 'economia', a administração e o governo da história dos homens (AGAMBEN, 2009, p. 36).

O alargamento do termo oikonomia ocorreu com Hipólito, importante teólogo da Igreja antiga, discípulo de Ireneu, e Tertuliano, apologista cristão, o primeiro a utilizar a palavra trindade. Ambos deslocam o termo do amplo 
domínio religioso a uma expressão estritamente técnica usada para a articulação da trindade divina. Contra aqueles que entendiam ser impossível conceber as três pessoas e um único Deus (sob pena de cair no politeísmo ou paganismo), esses teólogos dos primeiros séculos da Igreja recuperam o termo grego de administração da casa, dando-lhe novo sentido: assim como em uma casa o pai delega tarefas e funções aos filhos, mas nem por isso tem seu estatuto de pai questionado, ou seja, sua autoridade comprometida, da mesma maneira o Pai confere a gestão, a economia, a administração dos homens a seu Filho, não tendo por isso rebaixada a sua condição suprema de Deus que, quanto à sua substância, continua sendo uno e, quanto à economia, tríplice (AGAMBEN, 2011).

Os Padres capadócios, especialmente Gregório de Nazianzo e Gregório de Níssa, também contribuíram decisivamente para o fortalecimento do dogma trinitário. São eles que, de certa maneira, suavizam a fratura entre ser e práxis - a ideia era não enfatizar a existência de duas esferas distintas: natureza/essência de Deus e sua ação salvífica (práxis), mas demonstrar a especificidade de cada uma das duas racionalidades: a divina e a econômica, mais conhecida como economia da encarnação e da salvação. Cada uma delas, defendiam os capadócios, tem sua própria terminologia, e não devem ser confundidas entre si.

Observa-se que essas duas racionalidades, cuja ideia era mantê-las unidas, se davam por modo relacional, ou seja, o ser e a práxis de Deus relacionam-se mútua e ordenadamente. A união entre ser e práxis, transcendência e imanência, ocorre através da ideia de ordem (taxis), confirmada, curiosamente, por uma natureza econômica. O conceito de ordem vem da teologia de Aristóteles, em que transcendência e imanência são apresentadas como distintas, sendo a transcendência superior à imanência e, na articulação de ambas, instala-se uma máquina (providencial), ou uma teoria de governo divino no mundo (AGAMBEN, 2011).

A fratura originalmente exposta entre transcendência e imanência, advinda do aristotelismo, é ressignificada pela teologia cristã, de modo que o Deus cristão é esse em que ordem transcendente e ordem imanente 
relacionam-se mutuamente, passando de uma para a outra. Então, se o ser de Deus enquanto práxis de governo no mundo revela-se como uma oikonomia divina, Aristóteles, talvez sem querer, tenha legado à política do ocidente um paradigma econômico divino e gerencial.

Assim, temos que a oikonomia trinitária (articulações das três pessoas divinas: Pai, Filho e Espírito Santo), e o próprio governo do mundo (gubernatio), coincidem reciprocamente, ou seja, tudo diz respeito a uma oikonomia divina. Para Agamben (2011), as práticas político-jurídicas do mundo ocidental revelam-se como uma oikonomia, uma vez que se referem a uma única gestão econômica e divina - sendo este, justamente, o legado da teologia cristã à modernidade. Em outras palavras, a oikonomia é o governo no mundo e, por isso, este também se apresenta como providência - a providência articula-se como uma máquina, a gubernatio dei (governo de Deus), no governo divino do mundo (AGAMBEN, 2011).

A oikonomia, pontualmente por sua raiz administrativa e gerencial, pôde oferecer à teologia cristã um instrumento adaptável àquela difícil situação tanto da processão das pessoas da trindade quanto do governo de Deus no mundo.

O conceito de oikonomia é o operador estratégico que, antes da elaboração de um vocabulário filosófico apropriado, que só ocorrerá no decurso dos séculos IV e $\mathrm{V}$, permite uma conciliação provisória da trindade com a unidade divina. Assim, a primeira articulação do problema trinitário acontece em termos "econômicos", e não metafísico-teológicos, e, por esse motivo, quando a dogmática niceno-constantinopla alcança sua forma definitiva, a oikonomia desaparece progressivamente do vocabulário trinitário para se conservar apenas no da história da salvação (AGAMBEN, 2009, p. 37).

A construção desse paradigma resolve, por um lado, o problema da unidade do ser e pluralidade de ações, ontologia e história, organização interna da divindade e história da salvação. Mas, por outro lado, este paradigma permitirá pensar em um novo modo do entrecruzamento entre a teologia e a política, ou seja, a complexa relação entre reino (Deus), máxima dignidade, transcendente e sem ocupação - e o governo - a atividade imanente de um demiurgo ocupado com a administração das coisas mundanas. Essa cisão entre 
Reino e Governo está presente, segundo Agamben, no problema da oikonomia trinitária, o qual divide Deus entre seu ser e sua práxis (AGAMBEN, 2011).

Ao apontar a fratura existente na dogmática trinitária, o pensador afirma que, na tentativa dos teólogos de estancar a cesura no Ser de Deus (Deus uno e trino), eles formularam estrategicamente, por meio do dispositivo oikonomico, a doutrina trinitária. Esse artifício deveria suturar tal separação. Entretanto, eis que uma nova fratura reaparece: a cisão entre o Ser de Deus e sua ação no mundo, sendo esse o grande legado que a teologia cristã deixou ao ocidente. Então, o termo oikonomia serviu, na história da Igreja, entre o II e o VI séculos, para expressar uma certa pluralidade divina, não no plano do Ser de Deus, na ontologia, mas em sua práxis, no plano da oikonomia (AGAMBEN, 2009)². Em outras palavras, essa cisão rendeu ao ocidente a clara separação entre o que se é e o que se faz (opus operantum/opus operans; efetualidade/operatividade; reino/governo; política/economia). Essa tensão resultante da duplicidade paradigmática, iniciada anteriormente com a teologia cristã é, justamente, central no Projeto Homo Sacer, e a saída vislumbrada por Agamben é a desativação desses polos de tensões, profanando-os.

$\mathrm{Na}$ delicada construção da doutrina trinitária, Agamben (2011) argumenta que a cesura entre Deus e sua ação reafirmou-se, resultando em duas grandes classes, ontologia das criaturas e a oikonomia dos dispositivos. Oikonomia como dispositivo, para o pensador, tem por significado um conjunto de práxis e saberes cujo objetivo é controlar, governar e orientar os gestos e os pensamentos dos homens para tudo aquilo que se supõe útil. Assim, no atual desenvolvimento do capitalismo, observa-se a proliferação dos

\footnotetext{
${ }^{2}$ A doutrina trinitária da Igreja foi se solidificando na medida em que se defendia contra os ataques de várias, assim denominadas, "heresias"; estas questionavam a unidade de Deus com Cristo. Entre essas correntes, destacam-se o subordinacionismo, a qual reconhece que Cristo não atingiu o conceito de Deus único; o modalismo, defendido por Sabélio, que mais tarde será conhecido como sabelismo. Sabélio entende que na história da salvação, Deus assume três formas distintas: Pai, Filho, e Espírito Santo - três formas de manifestação do Deus único. Esses contrassensos tiveram desenlace no concílio de Nicéia em 325, cuja tese vencedora foi a do homousios, que se refere à unidade de Jesus Cristo com Deus: "O Filho unigênito de Deus é Deus de Deus, luz da luz, Deus verdadeiro de Deus verdadeiro, gerado, não criado, uma só essência com o Pai". A ontologia do Filho é uma discussão bastante profunda feita pelos cristãos nos primeiros concílios. Esse assunto foi mais bem desenvolvido no capítulo 2, "Oikonomia Trinitária", de Pfister (2019, p. 43).
} 
dispositivos em igual medida ao aumento de processos de subjetivação, os quais cada vez mais mascaram a identidade pessoal. Para o pensador, já se pode notar a existência dos dispositivos desde as origens do homo sapiens, mas não como hoje, em que tais dispositivos assumem caráter de totalidade na vida dos indivíduos, moldando-os e orientando praticamente todas as suas ações. Desse modo, até mesmo o evento que produziu o homem na chancela homo sapiens efetuou-se da fratura "que reproduz de algum modo a cisão que a oikonomia havia introduzido em Deus entre ser e ação. Esta cisão separa o vivente de si mesmo e da relação imediata com o seu ambiente [...]" (AGAMBEN, 2009, p. 43).

\section{O dispositivo Nudez-Veste}

Outro importante dispositivo associado à oikonomia é a nudez. Agamben reflete sobre o tema, afirmando que "a nudez, na nossa cultura, é inseparável de uma assinatura teológica" (AGAMBEN, 2015, p. 91), ou seja, é um conceito que assim como a oikonomia está enraizado na teologia cristã. Ao atuar como dispositivo, o conceito de nudez, certamente, marcado pela assinatura teológica cristã, foi condicionado aos limites deste campo, ou seja, essa prática demarcatória está inscrita num jogo de poder, de manipulação de relações, uma atividade de governo "sem nenhum fundamento no ser" que, de modo objetivo, implica a produção de sujeitos (subjetivação). A proliferação desses processos de subjetivação resulta, segundo Agamben (2015), no amplo e exagerado "mascaramento" do ser. Nessa perspectiva, o desnudamento foi construído sempre de modo negativo, o "ficar nu" no paraíso simbolizou a morte para graça divina, a expulsão do Éden que jogava a humanidade à sua própria sorte: "Do suor do teu rosto comerás o teu pão, até que tornes terra, porque dela foste tomado; porquanto és pó, e ao pó tornarás." (Gn 3,19). A vergonha da nua corporeidade, e tantos outros problemas relacionados ao corpo, ao sexo, podem originalmente advir deste dispositivo primitivo.

A temática da nudez evoca o Paraíso edênico, no qual Adão e Eva, mesmo antes da queda, do pecado original, já estavam, segundo a 
teologia, cobertos por uma veste de graça - ela os envolvia como um traje glorioso, a chamada "veste de luz". Agamben aponta o aparecimento da nudez em dois momentos marcantes: o primeiro, na rápida entrecena da percepção da nudez e a confecção da tanga e, o segundo, quando tiram as folhas de figueira para vestirem as túnicas - "E o Senhor Deus fez túnicas de peles para Adão e sua mulher, e os vestiu" (Gn 3,20). A nudez marcou a história da humanidade: antes de a conhecerem, todos viviam na graça plena de Deus e, após seu conhecimento, foram destinados ao trabalho e à morte. Nesse sentido, analisa o pensador italiano: "a nudez só acontece por assim dizer, negativamente, como privação da veste de graça e como presságio da resplandecente veste de glória [...]" (AGAMBEN, 2015, p. 93). A nudez profana só poderia acontecer, de forma integral, no inferno, e é talvez por isso que o cristianismo apresente uma Teologia da Veste em detrimento a uma Teologia da Nudez.

Dialogando novamente com os escritos de Erik Peterson, Agamben o aponta como um dos "raros" teólogos modernos que ousou se debruçar sobre o tema nomeando-o de "Teologia da veste". Peterson liga-se aos escritos agostinianos para fundamentar a teologia dos vestidos. Em De civitae Dei, Agostinho afirmava que embora Adão e Eva fossem criados num corpo animal e não espiritual, este corpo era revestido pela graça como uma veste, não conhecendo doenças e morte, bem como a libido, ou seja, a excitação descontrolável das partes íntimas (obscenae). Essa luta entre carne e espírito após o desnudamento paradisíaco é também relatada por Paulo em Gálatas "Andai pelo Espírito, e não haveis de cumprir a cobiça da carne. Porque a carne luta contra o Espírito, e o Espírito contra a carne; e estes se opõem um ao outro, para que não façais o que quereis" ( $\mathrm{Gl}$ 5,16-17).

Ao ligar diretamente nudez ao pecado, Peterson, na linha de Agostinho, aponta que na vida edênica havia uma não nudez mesmo na ausência de vestes. A nudez relaciona-se com o que a Escritura chama de "abertura dos olhos", a qual ocorre imediatamente após o pecado. $O$ 
homem existia para Deus e seu corpo, mesmo despido, não estava nu. Conforme Peterson,

Antes do pecado a relação do homem para com Deus era tal, que o seu corpo, apesar de ser sem vestido humano, não era "nú", porque a graça sobre-natural cobria a pessôa humana à semelhança de um vestido. $O$ homem não vivia somente sob a luz da glória divina, êle possuía a glória de Deus como um vestido (PETERSON, 1940, p. $465)^{3}$.

Na ocorrência do pecado, o homem sai deste estado da graça divina, assumindo sua natureza, que agora está completamente visível:

A queda da natureza humana pelo pecado é a causa do despojamento do corpo, da percepção da "nudêz". [...] pecando, perdeu o homem a glória divina: e logo o corpo tornou-se visível na sua natureza, sem a glória divina: a nudêz da méra corporalidade, um corpo sem nobreza - porque a sua dignidade essêncial estava fundada na glória divina, perdida pelo pecado (PETERSON, 1940, p. 465).

Para Agamben, Peterson é bastante enfático ao deixar clara sua preposição de que a graça envolvia a natureza humana como uma veste. Isto posto, toda problemática em torno da nudez revela-se numa complexa relação entre natureza e graça. O que o pensador italiano deseja demonstrar, pelos próprios escritos petersonianos, é que na medida em que a teologia apresenta a natureza humana como uma antecedente necessitada de veste - a veste da graça, despida pelo pecado, "significa que o pecado não introduziu o mal no mundo, mas simplesmente o revelou" (AGAMBEN, 2015, p. 100). A nudez revela, portanto, um resíduo imperfeito na constituição da criação, uma vez que o ser humano já carecia, desde o início, de uma veste, a veste da graça.

Na medida em que a teologia cristã prega o estado de graça vivido pelo homem antes do pecado, afirma-se, em outras palavras, que o homem e a mulher tinham total controle sobre sua sexualidade e, após o pecado, a nudez incita os órgãos genitais que corrompem a natureza, transmitindo

\footnotetext{
${ }^{3}$ Utiliza-se, aqui, a tradução publicada pela revista brasileira $A$ Ordem, em 1940. Optou-se por manterse, nas transcrições, a gramática e ortografia tal como se apresentam no original.
} 
essa mancha pela procriação. Tal processo é conhecido como pecado original $^{4}$. E é justamente aqui que o ofício, a operatividade da Opus Dei (da liturgia) $)^{5}$, adentra misteriosamente para ressignificar o conceito de nudez.

Com o Concílio de Trento (século XVI) a Igreja Católica ratifica, de uma vez por todas, o caráter eterno do sacerdócio de Cristo, de modo a renová-lo perpetuamente na liturgia eucarística (AGAMBEN, 2013). Agamben observa que o fundamento da Igreja está assentado em uma aporia, ou seja, como não pode ser repetida concretamente, a liturgia sacramental passa a ser entendida como "mistério", e a questão a que sempre se volta é: como o mistério passou a "ministério", a uma prática hierárquica de seus membros eclesiais? A própria doutrina trinitária, revelada em economia divina, tomou a forma de um

\footnotetext{
${ }^{4}$ No contexto da interpretação moral religiosa, Peterson escreve (1940, p. 465-467):

"Pelo pecado, o homem foi descoberto no seu próprio sêr - por isso, deveria ser coberta a nudês do corpo pelo vestido. O despojamento do corpo foi a causa da 'vergonha' - por isso exige a 'vergonha', o pudor, que o corpo seja coberto.

O corpo não sendo mais inocente, deve ser velado por meio do vestido. A corrupção deve ser escondida, e sôbre a putrefacção estende-se um pano.

O vestuário é, por assim dizer, uma interpretação do homem, porque o homem não tem a sua interpretação em si mesmo: a sua natureza tem uma relação essêncial e necessária com a graça e só por meio dela atinge a perfeição.

Em Adão, a "veste" da justiça sobrenatural, da inocência e da imortalidade, deixava perceber a sua dignidade e tornava visível o destino que Deus lhe preparára pelo dom da graça e da glória.

E não é só - a veste paradisíaca prova-nos, também, que a justiça, inocência e imortalidade, numa palavra: a graça sobrenatural, é uma cousa acessória, aperfeiçoando a natureza da Adão - como o vestuário é também só um acessório do homem e não uma parte integrante dêle.

E mais uma constatação - como o vestuário esconde o corpo, ainda encobre também a graça sobrenatural em Adão todas as possibilidades funestas de uma natureza humana, abandonada pela glória divina a si mesma: a depravação da natureza no sentido daquilo, que a Sagrada Escritura chama 'carne' - a revelação da 'nudês' do homem e da sua corrupção.

Tem, pois, um sentido profundo a tradição católica, quando chama a plenitude das graças do homem no paraízo, uma 'veste'. O homem recebe a interpretação do próprio sêr sómente pela veste da glória, a qual lhe é 'exterior' num certo sentido, como uma veste costuma ser. Mas, esta 'exterioridade' dum simples 'vestuário' nos ensina a verdade muito importante, que a graça supõe a natureza criada - sendo esta, por si mesma, sem vestuário e sempre no perigo dum despojamento, da 'nudês'.

Mais ainda - compreendemos assim, que o homem possa vestir-se de virtudes, sim - mas não possa revestir-se da justiça, inocência e imortalidade - e que, finalmente, a perda da veste da divina glória expõe à vista não mais a natureza sem vestuário (pura), mas, sómente a natureza despojada, cuja 'nudês' torna-se visível na 'vergonha'".

${ }^{5}$ Conforme a Constituição da Sagrada Liturgia, de 4 de dezembro de 1963, do "exercício da função sacerdotal de Jesus Cristo [...] na qual o culto público integral é praticado pelo corpo místico de Jesus Cristo, ou seja, pela cabeça e pelos seus membros" (AGAMBEN, 2013, p. 7).
} 
mistério. A formulação opus operatum e opus operantis também apareceu no Concílio de Trento, mas sua origem remonta às disputas a respeito da validade do batismo, ocorridas na Igreja entre os séculos III a IV. A questão central era garantir a eficácia do sacramento para além de qualquer motivo que pudesse torná-lo ineficaz. Escreve, nesse sentido, Agostinho: "aqueles que foram batizados por um bêbado, por um homicida ou por adúltero, se receberam o batismo cristão, foram batizados por Cristo" (AGOSTINHO apud AGAMBEN, 2013, p. 31). A Igreja, nesse sentido, prossegue Agamben, tal como qualquer instituição, quer assegurar que a função feita em seu nome sempre será válida, não importando quem o faça. O que está em jogo na distinção entre opus operatum e opus operantis é tornar evidente que a ação do sacerdote equivale àquela de um "instrumento animado", pois quem realmente irá agir é Cristo, cabendo ao sacerdote o "ministério do mistério". O efeito que deriva desta operação é a obra operada (opus operatum), o mistério.

$\mathrm{Na}$ medida em que o sacramento, ou o mistério litúrgico torna-se efetivo, a operatividade transborda em ação salvífica, em presença mistérica, de maneira que se pode dizer que a presença de Cristo coincide integralmente com a efetualidade do mistério litúrgico. E isso revela, para Agamben, uma mutação na ontologia clássica, pois "no ofício, ser e praxe, aquilo que o homem faz e aquilo que o homem é, entram em uma zona de indistinção [...]" (AGAMBEN, 2013, p. 9). No léxico da ontologia, ser e substância são independentes daquilo que produzem, de seus efeitos; já nesta ontologia da efetualidade de ordem litúrgica, o ser não se separa de seus efeitos, são eles que na verdade passam a determiná-lo. Nesse sentido, o ofício entendido como a praxe sacerdotal, passa a definir plenamente o ser, de maneira tal que "o sacerdote é aquele ente cujo ser é imediatamente uma tarefa e um serviço — isto é, uma liturgia" (AGAMBEN, 2013, p. 93). O sujeito, embora preconize a ação, é definido por ela; “isso e não outra coisa significa 'dever-ser”". O ofício e o dever foram colocados no centro da ética e da política moderna - eis aqui outro legado da liturgia cristã: a oikonomia (governo de Deus pelos homens) ou, em termos foucaultianos, a governamentalidade, tornam-se o coração da política ocidental. Por aquela, a vontade e a decisão, respaldadas nas formas 
litúrgicas religiosas - no caso das Igrejas - e seculares, no caso do Estado e das empresas, assumem, no ocidente, absoluta centralidade ${ }^{6}$.

Segundo o Catecismo da Igreja, o sacramento do batismo foi constituído para apagar o pecado original, daí o iniciado usar as vestes de linho branco em substituição à peliça, as vestes da vergonha:

Pelo Batismo, todos os pecados são perdoados: o pecado original e todos os pecados pessoais, bem como todas as penas do pecado. Com efeito, naqueles que foram regenerados não resta nada que os impeça de entrar no Reino de Deus: nem o pecado de Adão, nem o pecado pessoal, nem as sequelas do pecado, das quais a mais grave é a separação de Deus (CATECISMO DA IGREJA CATÓLICA, 2000, p. 351).

\section{Ou, em Peterson:}

Quem recebe a veste batismal, depõe o vestido que trazia depois da queda: o vestido feito de folhas de figueira estéril; os vestuários de peles de animais mortos, símbolos da nossa mortalidade, a veste da vaidade, de sedução, e de concupiscência, o vestido de "moda" e o trajo "civil" - todos estes despojos "sujos" deixamol-os, quando corremos o batismo. "Despidos e nús", como a natureza decaída o exige, que "nasce e morre núa" (Job, 1, 21) - aproximando-nos da pia batismal, para recebermos depois da morte mistíca do batismo (Rom, 6, 4) - a veste batismal, resplendente de glória, inocência e imortalidade.

O que o batismo prefigura "in signo" e opéra no Espírito Santo, torna-se perfeito na "eschatologia". Pois, o "mistério" da Igreja é um mistério "eschatologico". Porque recebemos justamente a veste batismal para "trazê-la sem mancha diante do Tribunal do Nosso Senhor Jesus Christo", sendo a veste branca o "símbolo da glória da ressureição" (Cat. Rom. 1. c)

E como o mistério do batismo é um "mistério de morte", na conformidade da morte de Cristo (Rom. 6, 3, ss), atinge o seu auge na morte física. No despojamento pela morte, nesta nudês perante o tribunal, depômos os últimos vestidos, aperfeiçoando

\footnotetext{
${ }^{6}$ Em Friedrich Nietzsche (2009), a internalização da disciplina ascética e de sua parceira, a culpa, gera o ressentido. Michel Foucault (1989) compreende o império da microfísica do poder na modernidade, lugar em que os indivíduos sujeitam-se a processos de disciplinamento extremo, tendo disposto inteiramente seus corpos ao conjunto de regras estabelecidos pelas instituições, pelo poder estatal e pelo poder econômico. Em Carl Schmitt (2006), a indiscernibilidade entre o ser e a práxis, responsável pelos processos de subjetivação, constitui-se enquanto ambiente propício para o estabelecimento do poder total do soberano. Aqui, o soberano é aquele que decide sobre o estado de exceção. Giorgio Agamben (2004) leva a sério a leitura de Schmitt e percebe que, na contemporaneidade, se estabeleceu uma verdadeira máquina antropológica em que o poder soberano, no âmbito político quanto na esfera econômica, gera o estado de exceção permanente, cujo subproduto é a re-criação do homo sacer, uma "anti-figura" jurídica que não corresponde, em qualquer aspecto, ao sujeito, porque não possui qualquer direito, a quem não se reconhece enquanto ser e a quem não se reconhece nem ao menos a mais remota possibilidade de agir.
} 
assim o que tínhamos começado no batismo. Mas ao sermos revestidos do corpo da ressurreição, da veste isenta de corrupção, receberemos visivelmente a plenitude dos bens, que já possuímos agora, no simbôlo da veste branca do batismo (Col. 3, 3) $[\ldots]$ (PETERSON, 1940, p. 470, 471).

Essa pesada herança deixada pela cristandade aprisiona-se na oposição nudez-veste, a qual também atua como um verdadeiro dispositivo na contemporaneidade. Para Agamben "a moda é a herdeira profana da teologia da veste, a secularização mercantil da condição edênica pré-lapsária" 7 (AGAMBEN, 2015, p. 116).

O dispositivo nudez-veste, trajado-nu, vestido-maltrapilho, reafirma-se cada vez mais nos dias de hoje numa intensa relação de poder. Ligado à rede da oikonomia que separa ser e práxis, o dispositivo nudez-veste continua separando o vivente de si mesmo, fazendo com que o traje seja mais importante que o ser já que o traje não é apenas uma vestimenta, mas um instrumento de poder. Em outras palavras o dispositivo nudez-veste carrega o aspecto político, que se impõe como uma fronteira social: a toga, o terno e a gravata, o jaleco, tecidos sofisticados, joias estão em condições de autoridade frente àqueles cobertos por tecidos ralos. Dessa maneira, o estatuto soberano se mantém precipitando a vida humana na condição de bando soberano ${ }^{8}$. "O

\footnotetext{
7 Vale, aqui, citar-se Peterson (1940, p. 469):

"Em suma, o vestido do homem decaído é uma lembrança do vestido perdido do homem paradisíaco. É uma lembrança tão viva, que cada mudança e cada renovação de vestido pela moda - que aceitamos de bôa vontade, porque as variações da moda parecem oferecer-nos tantas outras possibilidades de compreender melhor o nosso próprio sêr - cada mudança desperta e provoca sómente as saudades da veste perdida, a única capaz de revelar a nós mesmos o nosso próprio sêr, e de tornar visível a nossa 'dignidade'."

Agamben e Peterson abordam a questão de modos distintos: para este, a moda tenta fazer as vezes da veste de glória perdida pelo pecado original; para aquele, o ser humano busca encontrar, na moda, sua essência perdida, seu eu verdadeiro.

8 É criativa e pertinente a relação que Geraldo Luiz De Mori e Davi Mendes Caixeta (2020, p. 111) estabelecem entre a veste, a vergonha e o homo sacer (vida nua). Escrevem:

"Tendo em vista que a situação de nudez está presente tanto no pensamento teológico como na compreensão da biopolítica, é possível fazer uma aproximação entre o desnudamento e a vida nua. No caso do desnudamento, o ser humano antes estava envolvido com a veste da graça, que o dignificava, com justiça, inocência e incorruptibilidade. No caso da vida nua, a mera vida natural, zoé, se contrapõe à vida qualificada bíos, em que a pessoa tem alguma dignidade perante a sociedade. Dessa forma, pensa-se na analogia que pode existir entre a veste gloriosa e a bíos, a vida qualificada, uma vez que ambas apontam para a dignidade do ser humano.
} 
traje, nesse contexto, é elemento fundamental ao deslocamento do trajado para dentro e para fora do estado de exceção" (TEIXEIRA, 2017, p. 66).

\section{Forma-de-vida e a destituição do dispositivo}

Como a cesura entre o ser e a sua práxis, entre a existência e a normatividade, representa o eixo fundamental das pesquisas de Agamben, o autor procura possíveis rotas de fuga contra o forte jugo dos dispositivos sobre a vida no ocidente, encontrando possíveis pistas na vida monástica. Em Altíssima Pobreza: regras monásticas (2014), apresenta meios para destituir os dispositivos que aprisionam o viver humano criativo e verdadeiro. Parece ver na expressão forma-de-vida a chave para a liberdade em relação a determinado poder e a certas funções e operações instituídas no Estado secularizado. Nesse sentido, lembra a explosão de movimentos religiosos nos séculos XII e XIII, os quais questionavam as ações tanto da Igreja quanto de seus "indignos" sacerdotes, o que possibilitou o aumento na procura dos monastérios e da vida cenobita. Se antes ser cristão era considerado altamente radical e, até mesmo, subversivo, logo após a institucionalização do cristianismo como religião oficial por Constantino (272 d. C.-337 d. C), essa situação praticamente se inverteu e a Igreja passou a não apenas estabelecer relações com o Império, mas também a ser beneficiada pelos poderes políticos e econômicos concedidos pela coroa à esfera eclesial. Por isso, o monasticismo representa uma certa resistência à tentativa institucionalizante de capturar a vida cristã pelo Império romano.

Para Agamben (2014), o sintagma "forma de vida" parece assumir no franciscanismo um significado técnico em que a forma não é uma norma (regra) que se impõe à vida, mas um viver que, no ato de seguir a vida de Cristo, se dá e se torna forma, em outras palavras, a "forma de vida" franciscana acaba por neutralizar e transformar-se em uma "forma-de-vida" (hifenada), ou

Com o pecado, o ser humano foi desnudado da veste de glória, despojado da graça divina, expulso do paraíso. A consequência disso é que seu corpo se tornou corruptível, a morte se tornou próxima. Qualquer veste que portar não passará de uma veste de morte. Já o homo sacer também vive essa situação limite de ser matável, insacrificável, colocado no espaço de exceção, jogado no fundo do poço, à mercê do poder soberano que tem o direito de sua vida e sua morte". 
seja, uma vida que não se fundamenta apenas por ser integralmente ofício e liturgia. Aqui, a vida do monge não se diferencia de seu ato de seguir a Cristo.

$\mathrm{O}$ agir dos monges está sempre em profunda ligação com a vida cenobita: obra e vida encontram-se numa zona de indistinção - a vida do monge releva-se nas suas próprias práticas. Nesse sentido, Agamben afirma que "O hábito do monge não concerne, de fato, ao cuidado do corpo, mas é, sobretudo, morum formula, 'exemplo de um modo de vida"' (AGAMBEN, 2014, p. 26). Reside, aqui, uma contradição. Se, por um lado, o hábito espelha a forma de vida, por outro, o conjunto de representações que cada parte de suas peças assume ${ }^{9}$ resulta de um processo de moralização ${ }^{10}$ de suas condutas. Nesse sentido, a proposta de uma vida ética cede espaço para a existência de uma vida moral. Agamben (2014, p. 28) lembra que está presente, portanto, nesse contexto, o conflito entre duas máximas: de um lado, a afirmação de que "o hábito não faz o monge" e, de outro, de que "Kleiden machen Leut" ("a roupa faz a pessoa").

À medida que o monasticismo se opõe à ideia de um officium, de uma vida que se distingue entre indivíduo e função, passa a criar problemas no interior da Igreja, o que culmina na doutrina da efetividade sacramental da Opus Dei. O papa Inocêncio III, considerado um dos mais importantes papas da Idade Média, deixa ainda mais evidente essa indistinção entre opus operans e opus operatum, reiterando que, no sacramento do corpo de Cristo, o sacerdote que o efetua em nada pode alterá-lo, nem para o bem nem para o mal - "por isso, mesmo que a obra de quem faz por vezes possa ser imunda, a obra feita

\footnotetext{
${ }^{9}$ Cada peça da veste monástica carrega um significado preciso, remetendo à sua própria vida monacal. O capuz, por exemplo, que os monges devem usar de dia e noite é um alerta para que se mantenham na inocência e simplicidade das crianças. E todas as demais peças, as mangas curtas da túnica, a sobreveste, as sandálias, o cinto, todos, sem exceção, anunciam um significado destinado diretamente para a vida do monge (AGAMBEN, 2014).

10 Moralização que coaduna com a interpretação de tipo teológica, como a que Peterson promove: "Certamente, o homem no paraízo não trazia vestidos, hábitos criados, tão pouco os vestidos, os hábitos criados de suas 'virtudes'. (Sabemos que a ética e a teólogia moral falam das virtudes num sentido figurado como de outros tantos 'hábitos').

A justiça sobrenatural era o seu vestido, inocência e imortalidade eram os seus 'hábitos'. Quando, pois, se manifesta a nudês corporal, manifesta-se, ao mesmo tempo, a ausência da justiça, da inocência e da imortalidade" (PETERSON, 1940, p. 465).
} 
sempre será pura" (INOCÊNCIO III apud AGAMBEN, 2014, p. 124). Vida e ofício estão compreensivelmente para sempre separados.

A tensão entre vida-officium, forma de vida e ofício sacerdotal chega ao seu ponto explosivo quando esses movimentos espirituais passam a questionar a separação entre opus operans e opus operatum, partindo do pressuposto que, para a administração dos sacramentos, o que conta não é o ofício, o direito à hierarquia, mas a imitação da vida apostólica; a defesa pelo ofício é numericamente maior e, portanto, mostra a história, será aceita como verdadeira.

Ao lançar luz sobre a vida monástica em Altíssima Pobreza, Agamben (2014) parece ter encontrado uma outra saída àquela sugerida pela oikonomia - na sua origem, o paradigma monástico integra vida e forma, essência e operatividade, constituindo-se como potência que pode colocar por terra a cisão original entre o ser e sua ação. Nesse sentido, assim interpretamos, a fórmula "o hábito não faz o monge" ganha maior significação. É o que Francisco revela, quando opta por uma não veste, um conjunto de panos remendados que, em si, constituem-se como a própria negação de qualquer veste. No fundador da irmandade franciscana, a negatividade tem maior sentido, sendo a pedra de toque de uma vida que nega a propriedade e até a posse, de uma forma-de-vida que simplesmente usa o que a natureza Ihe oferta.

A inoperosidade é, em nosso entendimento, o ato de retirar do ofício ou, de modo geral, das atitudes destinadas a produzir um efeito exterior, por exemplo os sacramentos, seu poder como tal. No propósito franciscano, o efeito não deverá ser obtido mediante a operação ritual, mas é um estar acontecendo dia a dia, em cada momento, por isso a expressão agambeniana forma-de-vida hifenada, justamente por se tratar de uma vida que se completa inteiramente à sua forma; não é preciso haver rituais litúrgicos para acontecerem os efeitos, mas somente viver a vida para que eles aconteçam. Não é a norma que acorrenta a vida como reza o paladino operativo, mas norma e vida harmonizam-se de tal modo que é impossível distingui-las entre si. O fato de vida e norma tornarem-se indiscerníveis aponta para um horizonte 
uníssono e não discordante entre esses dois polos: eis a tarefa para dar cabo ao projeto da oikonomia providencial.

\section{Considerações finais}

Conforme procurou-se demonstrar, Giorgio Agamben analisa os motivos pelos quais o poder, no ocidente, foi assumindo a forma de uma governamentalidade, tal como descrito por Michel Foucault. Sua tese central é de que tanto o Estado moderno quanto o contemporâneo ergueram-se sobre a violência, o bando soberano, ou, ainda, que na formação dos Estados Constitucionais está a gênese do estado de exceção: uma liberalidade que, a partir mesmo da lei, transborda os seus próprios limites. O pensador perscruta a finalidade primeira do poder, ou seja, como se estabeleceu o "governo dos homens".

Em O Reino e a Glória (2011), investiga os primeiros séculos da teologia cristã, dando certa continuidade às evidências deixadas por Foucault quanto à relação originária entre as técnicas governamentais do pastoreio cristão e o modelo de governo político configurado mais adiante. A governabilidade moderna seria algo como uma secularização do providencialismo teológico, que sai da esfera divina desdobrando-se na história humana. Por outro lado, a oikonomia (administração) aparece como recurso bastante estratégico que conciliou a trindade (Pai, Filho, Espírito Santo) com o monoteísmo, ou seja, as três pessoas da trindade não dizem respeito à ontologia do Ser divino, mas apenas e tão somente à sua forma de administrar - a oikonomia trinitária é, portanto, como Deus administra e governa, com o auxílio do ministério dos anjos, a vida divina e o mundo criado.

Nesse sentido, a "administração", o "governo" desta oikos, realizada pelos homens, é fundamentada na liturgia e no ofício, analisados pelo autor em Opus Dei (2013), obra em que demonstra por que o mistério litúrgico, revelado liturgicamente, é a chave para se compreender como a modernidade forjou tanto a ética quanto a ontologia, tanto a política quanto a economia do nosso tempo. 
Por trás desse "mistério litúrgico" encontram-se as poderosas formulações opus operatum e opus operantis, que garantem a eficácia do sacramento para além de qualquer motivo que pudesse torná-lo inócuo ou inoperante. Assim, os sacerdotes, enquanto ministros dos sacramentos, realizam sua função sacerdotal como um "fazer as vezes de Cristo", assumindo, por conseguinte, caráter vicário (AGAMBEN, 2013).

O teólogo Erik Peterson (1940), ao apresentar sua Teologia da Veste (Theologie des Kleides), defende que, antes do pecado, a criatura, embora estivesse nua, já estava coberta pelo véu da graça, vestia o traje glorioso, as “vestes de luz" e, após a expulsão do paraíso, as túnicas de pele, ou peliças, foram pejorativamente chamadas de símbolos de morte em oposição à veste de linho branco que o batizado receberá pelo sacramento do batismo. Assim, através da operação batismal feita pelos ministros da Igreja, o ser humano é liberto do pecado e regenerado como filho de Deus. Essa análise é inspiradora, e motiva Giorgio Agamben (2015) a refletir sobre a nudez. Conforme o pensador italiano, a nudez, em nossa cultura ocidental, é inseparável de uma assinatura teológica. As assinaturas são conceitos que se deslocam de um âmbito para outro, atuando como signos que remetem sempre à sua anterior filiação; no caso da nudez, à esfera teológica. À vista disso, a nudez encontrase sempre como algo negativo, indevido, impuro, que necessita ser escondido; como na condição edênica estava coberta pelas vestes de luz, na oikonomia divina não deverá ser diferente: será operada pelas mãos do sacerdote que, quando mergulha o catecúmeno na água, o regenera e o renova pelo Espírito Santo. Nesse sentido, o batizado, com as vestes brancas, liberta-se do pecado original (cf. $\mathrm{Gl}$ 3,27). Por outra via, parece que o efetivo agir litúrgico dissipa-se com o arrojado habitus do monge, apresentado pelo autor em Altíssima Pobreza (2014), pois este não remete simplesmente ao cuidado do corpo, mas é, sobretudo, a sua morum formula, exemplo de um modo de vida.

A relação nudez-veste, solidamente orientada pela teologia cristã, instituiu-se como o primeiro e talvez o mais inabalável dispositivo na cultura ocidental, de tal modo que o "estar nu” remete sempre à vergonha, proibição, constrangimento, um verdadeiro incômodo. 
É por essa razão que Agamben se propõe a compreender a nudez fora da assinatura teológica que a precede para, assim, ser neutralizada enquanto dispositivo, algo que os franciscanos espirituais parecem ter conseguido realizar. Ao debruçar-se sobre o monacato cristão, Agamben reflete acerca da forma-de-vida, uma vida que dá a si mesma sua norma de viver, distanciandose da vida respaldada pelo officium, pelas regras, pela positividade do direito. A partir de Agamben, pode-se pensar na nudez como chave libertária: por oposição a Peterson, não se dá, aqui, nem a nudez vestida da glória celestial que corresponde à pureza da criatura original — nem a nudez que envergonha, fruto da transgressão ao interdito. Analisar e contrapor os dispositivos de maneira a profaná-los, ou torná-los inoperosos, permite que se veja tanto a "peliça" quanto o "linho branco" como "nada", ou seja, há que se fazerem novos usos, que não estejam sentenciados pelo poder soberano gerador de violência e exclusão.

\section{Referências}

AGAMBEN, G. Altíssima Pobreza. São Paulo: Boitempo, 2014.

AGAMBEN, G. O Reino e a Glória. São Paulo: Boitempo, 2011.

AGAMBEN, G. Nudez. Belo Horizonte: Autêntica, 2015.

AGAMBEN, G. O que é o Contemporâneo? e outros ensaios. Chapecó: Argos, 2009.

AGAMBEN, G. Opus Dei: arqueologia do ofício. São Paulo: Boitempo, 2013.

AGAMBEN, G. Homo Sacer: O poder soberano e a vida nua I. Belo Horizonte: Editora UFMG, 2004.

A BÍBLIA Sagrada: Antigo e Novo Testamento. Trad. João Ferreira de Almeida. Ed. rev. atual. no Brasil. Brasília: Sociedade Bíblia do Brasil, 1969.

CATECISMO DA IGREJA CATÓLICA. São Paulo: Loyola, 2000.

DE MORI, G. L.; CAIXETA, D. M. Considerações teológico-políticas sobre nudez, desnudamento e vida nua em Giorgio Agamben. Rever, São Paulo, v. 20, n. 1, p. 97-113, jan./abr. 2020.

FOUCAULT, M. Microfísica do Poder. 8ª ed. Rio de Janeiro: Edições Graal, 1989. 
NIETZSCHE, F. Genealogia da Moral. São Paulo: Companhia das Letras, 2009.

PETERSON, E. Teologia do Vestuário. A Ordem, Rio de Janeiro, v. XXIV, p. 463-471, jul./dez. 1940.

PFISTER, M. Oikonomia trinitária na obra de Giorgio Agamben: entre O reino e a glória, Opus dei e Altíssima pobreza. Dissertação (Mestrado em Ciências da Religião) Pontifícia Universidade Católica de Campinas, Campinas, 2019.

SCHMITT, C. S. Teologia Política. Belo Horizonte: Del Rey, 2006.

TEIXEIRA, E. T. O dispositivo da veste e a censura entre ser e práxis: pensando um poder não fazer. Cadernos de Ética e Filosofia Política, n. 30, p. 52-74, 2017.

RECEBIDO: $23 / 07 / 2019$

RECEIVED: 07/23/2019

APROVADO: $19 / 11 / 2020$

APPROVED: $11 / 19 / 2020$ 